\title{
S. Kovalevskii
}

Kharkiv National University named after Air Force. Ivan Kozhedub, Kharkov

\section{STUDY OF DETECTION AND RADAR STEALTH PINPOINT AIR OBJECTS}

\begin{abstract}
The subject study of the article is to identify radar stealth and pinpoint aerial objects used in the national economy during their operation. The article is research process efficiency in detecting radar stealth and pinpoint aerial objects. The problem to be solved - just ification of technical solutions and their implementation in practice of detecting radar stealth and pinpoint air objects will improve efficiency in their radar detection by applying detection device using stealth and pinpoint lights overhead objects used in the national economy, which is offered. The article reviewed: promising ways to improve the detection of small aircraft and stealth objects of the simultaneous use of its properties and effective surface scattering algorithm using optimal processing signals reflected stealth and pinpoint objects in the air and block diagram using backlight stealth and pinpoint multiple objects overhead space-spaced transmitter block diagram detection device using the backlight stealth and pinpoint multiple objects overhead space-spaced transmitters, which corresponds to one volume and one separate speed channel being developed. Conclusion: The proposed technical solutions should be used as the modernization of existing radars and in creating advanced radar designs.
\end{abstract}

Keywords: subtle and pinpoint Air facilities, the effective surface scattering algorithm for optimal signal processing.

\section{Introduction}

Formulation of the problem. Considering the importance of stealth and pinpoint aerial objects in the economy in recent years has increased the need to study traditional methods of determining efficiency of small and inconspicuous air objects that will help determine the number of radar stations, in order to reduce power consumption and, consequently, to reduce the cost of creating and maintaining regular radar field. Resolving the contradiction between the tendency to reduce radar visibility stealth and pinpoint aerial objects and features of existing radars on their detection requires the development of new alternative and non-traditional methods of radar stealth and pinpoint overhead objects, confirming the relevance of research and application.

Analysis of the literature. Principles and organizational framework radar described in the literature [1 - 14]. Evaluating the effectiveness of the use of diversity reception of signals in radar observation stations upon detection of small air objects brought in [15]. Method of increasing the detection zone of small objects in the air radar observation stations set out in the theses of the report [16].

The question of improving the efficiency of detection of small objects overhead by combining methods Injection and diversity reception of signals contained in the theses of the report [17]. The basic principles of the use of modern radar world explored in [18]. At the same time remain open issues related to solving the contradiction between the tendency to reduce radar visibility stealth and pinpoint aerial objects and features of existing radars on their detection.

The article is a research process efficiency in detecting radar stealth and pinpoint targets.

\section{Core material}

Currently, promising ways to improve the detection of small and inconspicuous air facilities are [15]:

- the use of energy sources other radiation modes and implementing diversity reception;
- the use of resonant reflection properties of electromagnetic waves and subtle air of small objects when using wavelengths that are comparable to the size of the object;

- the benefits of diversity reception.

The use of multiposition radar system compared to the radar Injection [18] together with certain shortcom ngs have several advantages. As a Multi-transmitter radar can be used as a special (characteristics of the classical radar) and unconventional (external) transmitter that is not part of the system. With this construction system provides minimal energy consumption for the system.

At present the existing radar systems performing detection of stealth and pinpoint aerial objects in the field of illumination sources other radio and take advantage of diversity reception. As such sources are used transmitters broadcasting systems, cellular and others. In order to detect stealth aircraft and pinpoint objects with simultaneous use of its properties and effective surface scattering is necessary to provide a radar implementing their detection algorithm with its irradiated multiple transmitters. For this radar processing channels need to implement echo signals caused by the radiation of their own and third-party transmitters [7]:

- channel processing the echo signals reflected from stealth and pinpoint aerial objects at its irradiation transmitter, which combined with receivers (using properties effective surface scattering);

- channels of processing the echo signals reflected from stealth and pinpoint aerial objects at its irradiation transmitters are spaced (using properties effective surface scattering).

For processing the echo signals from each transmitter in the reception center must implement separate processing channels. The signals emitted by transmitters spaced, in general, can be incoherent with each other. As shown [7], the fluctuation amplitude of the reflected signals in monostatychnomu and bistatychnomu modes correspond to different distribu,-ions, so independent. 
Algorithm for optimal processing signals reflected stealth and pinpoint objects in the air and regime should be based on the principle of non-coherent summing results agreed with appropriate compensation rocessing time and frequency shifts that would allow radar, to improve the quality of detection of small and inconspicuous air objects to realize multi incoherent detection method of union channels. This can be done by using additional outside sources of radiation. That is not possible without the improvement and implementation of multi-detection method stealth and pinpoint aerial objects incoherent union channels. onsider this method using radiation else.

Determines that while in stealth aircraft and pinpoint objects in the field of radiation transmitting multiple positions reflected from it echo signals at the location of the receiving position can be represented as:

$$
Y_{k}(t, \vec{\lambda})=\left\{S_{1 k}\left(t, \vec{\lambda}_{1}\right), \ldots S_{i k}\left(t, \vec{\lambda}_{i}\right) \ldots S_{N k}\left(t, \overrightarrow{\lambda_{n}}\right)\right\}
$$

where $Y_{k}(t, \vec{\lambda})$ - the combined signal to the receiving position at the location, which is caused by signals eflected from stealth and pinpoint aerial objects located in the k-th separate volume; $S_{i k}\left(t, \vec{\lambda}_{i},\right)$ - and the second type of signal due and th transmitter and reflected by stealth and pinpoint aerial objects located in the k-th separate volume; $\vec{\lambda}$ - vector informative parameters total signal composed of vectors $\vec{\lambda}_{i} ; \vec{\lambda}_{i}$ - vector informative parameters of the echo signal and the second type; $i=1,2 \ldots N$ - the number of types of signals due to the number of gear positions, irradiated stealth and pinpoint aerial objects.

Each signal $S_{i k}\left(t, \vec{\lambda}_{i},\right)$ which is part of the total signal (1) at the location of the receiving positions are mutually uncorrelated and can be accepted and processed according to individual receiving channels. Therefore, to enable processing of the entire set of signals $Y_{k}(t, \vec{\lambda})$, Reception center should consist of a combination of certain processing channels. Each eceiving channel operates algorithm [8]:

$$
Z_{i k}=\int_{0}^{T}\left\{Y_{k}(t, \vec{\lambda})-D_{i k}\left(t, \vec{\lambda}_{i}\right)\right\} X_{i k}\left(t, \vec{\lambda}_{i}\right) d t
$$

where $Z_{i k}$ - the result of coordinated processing the echo signal and the second type received from stealth and pinpoint aerial objects located in the $\mathrm{k}$-th separate volume; $Y_{k}(t, \vec{\lambda})$ - the combined input signal at the output of the receiver, which is reflected by stealth and pinpoint aerial objects located in the k-th separate volume; $D_{i k}\left(t, \vec{\lambda}_{i}\right)$ - standard grade component input, which is formed at the exit barriers for the equalizer and Channel processing and for the first separate volume;

$$
X_{i k}\left(t, \vec{\lambda}_{i}\right) \text { - Expected (reference) signal and the }
$$
second type for $\mathrm{k}$-th separate volume.

Optimal aggregate processing signals, which is based on the principle of non-coherent summing results coherent processing echo signals in the receiving hannels and generates corresponding likelihood ratio has the form [7]:

and

$$
\begin{aligned}
& L_{1}=\sum_{i=1}^{m} \frac{A_{i 1}^{2}}{N_{i}^{2}}\left|\tilde{Z}_{i}\right|^{2}, \\
& L_{2}=\sum_{i=1}^{m} \frac{1}{N_{i}}\left|\tilde{Z}_{i}\right|^{2}
\end{aligned}
$$

where L1, L2 - likelihood ratio of weak and strong ignals, respectively; $A_{i 1}=P_{i} / P_{1}$ - the ratio of average power signals in the i-th and the first channel; $N_{i}$ sided power spectral density of white noise in the i-th channel; $Z_{i}$ - the result of coherent processing of received signals in the i-th channel; $m$ - number of noncoherent processing channels.

Optimal treatment (2), (3), (4) which provides etection of small and subtle air of irradiation facilities with multiple transmitters is reduced to a coherent rocessing received echo signals quadratic detection in each channel processing and weight summing outputs of detectors all channels. The weights depend on the ignal / noise ratio and noise spectral density in the channels of processing. While processing channels are in a reception center, but emitters probing signals that cause the echo signals corresponding processing channels, separated in space. Thus, the echo signals reflected from one stealth and pinpoint air conditioned facilities and probing signals emitted from spatially separated positions, the receptionist positions will have different time delays and Doppler frequency. Therefore incoherent summation according to (3) or (4) must be implemented for each separate volume radiolokatsinoyi station prior to compensation of time delay and Doppler frequency for each reception channel to a separate volume radiolokatsinoyi station. With this in mind, the expressions (3) and (4) take the form:

$$
\begin{gathered}
L_{1}\left(d_{k}, \beta_{k}, \varepsilon_{k}, F \partial_{\kappa}\right)= \\
=\sum_{i=1}^{m} \frac{A_{i 1}^{2}\left(d_{k}, \beta_{k}, \varepsilon_{k}, F \partial_{\kappa}\right)}{N_{i}^{2}\left(d_{k}, \beta_{k}, \varepsilon_{k}, F \partial_{\kappa}\right)}\left|\tilde{Z}_{i}\left(d_{k}, \beta_{k}, \varepsilon_{k}, F \partial_{\kappa}\right)\right|^{2}
\end{gathered}
$$

and

$$
\begin{gathered}
L_{2}\left(d_{k}, \beta_{k}, \varepsilon_{k}, F \partial_{\kappa}\right)= \\
=\sum_{i=1}^{m} \frac{1}{N_{i}\left(d_{k}, \beta_{k}, \varepsilon_{k}, F \partial_{\kappa}\right)}\left|\tilde{Z}_{i}\left(d_{k}, \beta_{k}, \varepsilon_{k}, F \partial_{\kappa}\right)\right|^{2},
\end{gathered}
$$

where $L_{1}\left(d_{k}, \beta_{k}, \varepsilon_{k}, F \partial_{\kappa}\right), \quad L_{2}\left(d_{k}, \beta_{k}, \varepsilon_{k}, F \partial_{\kappa}\right) \quad$ ikelihood ratio of weak and strong signals in the k-th separate volume coordinates $\left(d_{k}, \beta_{k}, \varepsilon_{k}\right)$ and for the first Doppler frequency $F \partial_{\kappa}$ respectively; $d_{k}, \beta_{k}, \varepsilon_{k}$ - range, azimuth and elevation responsible for th separate volume station; $F \partial_{\kappa}$ - Doppler frequency, which is responsible for th separate channel Doppler frequency; $A_{i 1}\left(d_{k}, \beta_{k}, \varepsilon_{k}, F \partial_{\kappa}\right)$ - the ratio of average signal power 
in the i-th and the first channel for the k-th separate olume and for the first Doppler frequency resolution station; $N_{i}\left(d_{k}, \beta_{k}, \varepsilon_{k}, F \partial_{\kappa}\right)$ - sided power spectral density of white noise in the i-th channel element, which is responsible for th separate volume and for the first oppler frequency resolution station; $\tilde{Z}_{i}\left(d_{k}, \beta_{k}, \varepsilon_{k}, F \partial_{\kappa}\right)$ - the result of coherent processing of received signals in the i-th channel element, which is responsible for th separate volume and for the first Doppler frequency resolution station. As seen from expressions (2), (3), (4) each receiving channel and signal-type must be multi-in range (time delay) and speed (Doppler frequency).

Each channel compensation range operation erformed pereshkodovyh signals and channels formed
Fd1_i speed ... Fdm_i. The output of the high-speed amplitude detection channels after forming coherent processing results echo signal and the second type received from the software, which is a $\mathrm{k}$-th separate volume for $\mathrm{k}$-th speed channel $\left(Z_{i k}\right)$. Results coherent processing the echo signals arriving at the weighted summation. The weights $\left(Q_{k i}\right)$ are formed for each signal-type and each channel k-th distance and speed. The input adder come outputs of each channel signal and the second type, which correspond to the eponymous eponymous separate volume and channel speed. Some structural diagram of the device detection using stealth and pinpoint lights overhead objects more space-spaced transmitters that meets the eponymous separate volume and speed channel shown in Fig. 1.

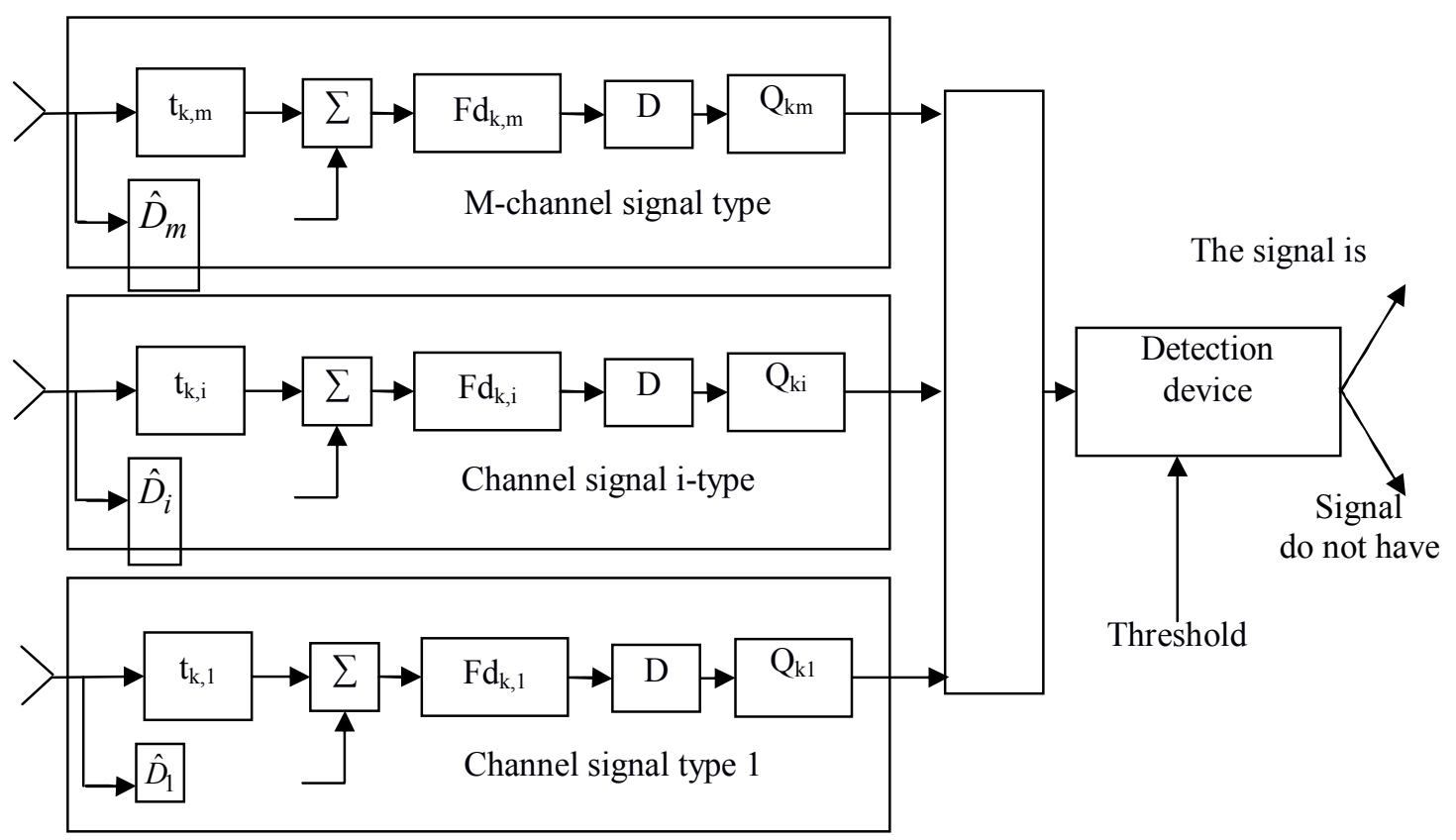

Fig. 1. Block diagram of the detection device using the backlight stealth and pinpoint multiple objects overhead space-spaced transmitters, which corresponds to one volume and one separate speed channel

As shown in Fig. 1, the construction of the radar system consists of a receiving and transmitting multiple positions, the optimal detection device is multi-channel. Signals receiving channels are aligned to the delay according to the delay values $t k 1 \ldots t k m$, which is caused by the different distances between the receiving and transmitting positions. Aligned to delay signals are coherent Doppler processing and filtering ( Fdkl ... $F d k m)$, detected and summed with weights ( $Q k 1 \ldots$ $Q \mathrm{~km}$ ). The coefficients depend on the signal / noise ratio in the channel processing.

The output of the adder gained through the signal (calculated likelihood ratio) is fed to a threshold device, which is compared with the threshold value depends on the selected detection criteria (minimum average risk, minimax, Neyman-Pearson, ideal observer, etc.). epending on exceeding or not exceeding the threshold decision on the presence or absence of stealth and inpoint aerial objects in the $\mathrm{k}$-th separate volume and speed k-th channel.

\section{Conclusions}

1. The paper identified ways to improve detection of subtle and objects.

2. To identify and pinpoint subtle objects in the air radar stations by using radiation sources is necessary to ensure third-party reception processing coherent echo signals outside sources, differences in compensation for the delay and Doppler frequency relative volume separate radar, incoherent weighted summation.

3. In evaluating the performance of small and detect stealth aircraft objects using third-party sources of radiation necessary to consider the nature of the fluctuations of the amplitude of the echo signals resulting from the properties and effective surface scattering stealth and pinpoint aerial objects.

4. The proposed technical solutions should be used as the modernization of existing radars and in creating advanced radar designs. 
REFERENCES

1. Klimchenko V.I., Kukobko S.V., Tyutyunnik V.A., Byelavin A.V. Potential RTI radar to detect operational-tactical and tactical unmanned aerial vehicles. New technologies - to protect airspace: Abstracts reported. 13 Science. Conf. Hark. nat. Univ Air Force them. John Kozhedub (Kharkov 12-13 apr. 2017). H .: HNUPS, 2017. P. 210.

2. Kuzmin SZ Tsyfrovaya radiolocation. Introduction to the theory. K .: Publishing "KVITS." 2000. 428 p.

3. Radioelectronic systems: Fundamentals and building a theory. Directory / ed. Y.D. Shyrman. - 2nd ed. - Moscow: Radiotechnics, 2007. - $512 \mathrm{p}$.

4. Farina, A., F. Studer Tsyfrovaya obrabotku radyolokatsyonnoy information. Soprovozhdenye purposes. M .: Radio and ommunication, 1993. $320 \mathrm{p}$.

5. Blyahman AB, IA Runov Effective Bystatycheskaya Square and scattering detection for objects in the radiolocation lumen. Radiotechnics and Electronics. 2001. T. 46. № 4. P. 424-432.

6. Blyahman AB, Myakynkov AV Rыndыk AG .. Measurement coordinate goals in trehkoordynatnыh bystatycheskyh with radar detection "in the lumen." Radiotechnics and Electronics. 2006. №4. P. 422-427.

7. Chernyak V. Mnohopozytsyonnaya radiolocation. M .: Radio and communication. 1993. $416 \mathrm{p}$.

8. Donets V., Kuchuk N., Shmatkov S. Development of software of e-learning information system synthesis modeling process. Сучасні інформачійні системи. 2018. T. 2, № 2. C. 117-121. DOI: https://doi.org/10.20998/2522-9052.2018.2.20

9. Svyrydov, A., Kuchuk, H., Tsiapa, O. (2018), "Improving efficienty of image recognition process: Approach and case study", Proceedings of 2018 IEEE 9th International Conference on Dependable Systems, Services and Technologies, DESSERT 2018, pp. 593-597, DOI: http://dx.doi.org/10.1109/DESSERT.2018.8409201

10/ Mozhaev O. Multiservise network security metric / O. Mozhaev, H. Kuchuk, N. Kuchuk, M. Mozhaev, M. Lohvynenco // IEEE Advanced information and communication technologies-2017. Proc. of the 2th Int. Conf. - Lviv, 2017. - P. 133-136. DOI: https://doi.org/10.1109/AIACT.2017.8020083

11. Kovalenko, A. and Kuchuk H. (2018), "Methods for synthesis of informational and technical structures of critical application object's control system", Advanced Information Systems, Vol. 2, No. 1, pp. 22-27, DOI: https://doi.org/10.20998/25229052.2018.1.04

12. Ruban, I. Redistribution of base stations load in mobile communication networks / I. Ruban, H. Kuchuk, A. Kovalenko // Innovative technologies and scientific solutions for industries. - 2017. - No 1 (1) - P. 75-81. - DOI : https://doi.org/10.30837/2522-9818.2017.1.075

13/ Kuchuk G., Kovalenko A., Komari I.E., Svyrydov A., Kharchenko V. Improving big data centers energy efficiency: Traffic based model and method. Studies in Systems, Decision and Control, vol 171. Kharchenko, V., Kondratenko, Y., Kacprzyk, J. (Eds.). Springer Nature Switzerland AG, 2019. Pp. 161-183. DOI: http://doi.org/10.1007/978-3-030-00253-4 8

14. Kuchuk G., Nechausov S., Kharchenko, V. Two-stage optimization of resource allocation for hybrid cloud data store. International Conference on Information and Digital Technologies. Zilina, 2015. P. 266-271. DOI: http://dx.doi.org/10.1109/DT.2015.7222982

15. Kowalewskii S. Evaluating the effectiveness of the use of diversity reception of signals in radar observation stations air the detection of small objects. Weapons systems and military equipment. Science journal. 2015. number 3 (43). S.89-92.

16. Kowalewski S.M., Tyutyunnik V.A., Hudov G.V. Method of increasing the detection zone of small objects in the air radar observation stations, radar troops.New technologies - to protect airspace: Abstracts reported. 12 Science. Conf. Hark. Univ Air Force them. John Kozhedub (Kharkov 13-14 apr. 2016). H .: Hoopes, 2016. P. 187.

17. Kowalewskii S.M., Hudov G.V., Lishchenko S.M. Improved detection of small objects overhead by combining methods Injection and diversity reception of signals. Creation and modernization of armament and military equipment in modern terms: Abstracts reported. 16 nauk.-Tech. Conf. (Chernihiv 8-9 sep. 2016). Chernigov: DNVTS, 2016 S. 128-130.

18. Griffiths HD From a Different Perspective: Principles, Practice and Potential of Bistatic Radar. International Conference on Radar. (Adelaide, Australia, 3-5 September 2003). Adelaide, 2003 R. 1-7.

Received (Надійшла) 11.12.2019

Accepted for publication (Прийнята до друку) 29.01.2020

\section{Дослідження виявлення радіолокаційними станціями малопомітних та малорозмірних повітряних об'сктів}

\section{С. М. Ковалевський}

Анотація. Предметом вивчення в статті $є$ виявлення радіолокаційними станціями малопомітних та малорозмірних повітряних об'єктів, що використовуються в народному господарстві в процесі їх експлуатації. Метою статті $\epsilon$ дослідження процесу підвищення ефективності радіолокаційних станцій при виявленні малопомітних та малорозмірних повітряних об' єктів. Задача, що вирішується, - обгрунтування технічних рішень, впровадження яких в практику виявлення радіолокаційними станціями малопомітних та малорозмірних повітряних об' єктів дозволять підвищити ефективності радіолокаційних станцій при їх виявленні шляхом застосування приладу виявлення при використанні підсвічування малопомітних та малорозмірних повітряних об'єктів, що використовуються в народному господарств, якій пропонується. В статті розглядається: перспективні шляхи підвищення ефективності виявлення малопомітних та малорозмірних повітряних об'єктів із одночасним використанням властивостей його бістатичної та моностатичної ефективної поверхні розсіювання, використання алгоритму оптимальної обробки сигналів, які відбиті малопомітних та малорозмірних повітряних об'єктів в моностатичному та бістатичному режимах, структурна схема виявлювача при використанні підсвічування малопомітних та малорозмірних повітряних об'єктів декількома просторово-рознесеними передавачами структурна схема приладу виявлення при використанні підсвічування малопомітних та малорозмірних повітряних об'єктів декількома просторово-рознесеними передавачами, яка відповідає одному роздільному об'єму та одному швидкісному каналу, , що розробляється. Висновки: запропоновані технічні рішення доцільно використовувати як при модернізації існуючих радіолокаційних станцій, так і при створенні перспективних зразків радіолокаційних станцій.

Ключов і слов а : малопомітні та малорозмірні повітряні об'єкти, ефективна поверхня розсіювання, алгоритм оптимальної обробки сигналів. 